Отримано: 20 січня 2020 року

Прорецензовано: 23 січня 2020 року

Прийнято до друку: 29 січня 2020 року

e-mail: muntonya@gmail.com

shpirinka@gmail.com
Muntian A. O., Shpak I. V. Verbalization of female artistic images in "A Thousand Splendid Suns" by Khaled Hosseini: gender aspect. Наукові записки Начіонального університету «Острозька академія»: серія «Філологія». Острог: Вид-во НаУОА, 2020. Вип. 9(77). C. $185-188$.

DOI: $10.25264 / 2519-2558-2020-9(77)-185-188$

Antonina O. Muntian,

Candidate of Philological Sciences, Associate Professor,

Dnipro National University of Railway Transport after V. Lazaryan

Iryna V. Shpak,

Candidate of Philological Sciences, Associate Professor,

Dnipo National University of Railway Transport after V. Lazaryan

\title{
VERBALIZATION OF FEMALE ARTISTIC IMAGES IN “A THOUSAND SPLENDID SUNS” BY KHALED HOSSEINI: GENDER ASPECT
}

The purpose of this study is an attempt to examine women's artistic images and their verbalization in Khaled Hosseini's novel "A Thousand Splendid Suns". In this study, the authors try to analyze the manifestations of the feminine discourse of the two main female characters in the novel "A Thousand Splendid Suns" in sociocultural and linguostylistic aspects. In the recent years women's studies are becoming more and more significant; female discourses are being analyzed form different scientific points of view. Considering the relevant scientific works of eminent scientists, the authors of this article conclude that artistic images play an extremely important role in the implementation of current topics and ideas of any literary work: artistic images have the ability to produce new ideas and communicate these ideas to readers who in their turn could interpret them according to the cultural background, which ensures the formation of the linguistic and cultural concepts. Khaled Hosseini's female characters' discourse in his novel "A Thousand Splendid Suns" is multilayered: on the one hand, it is actualization of the personal fight for basic human rights within family hierarchy (cultural aspect) and on the other hand, it is the fight for civil rights from the point of view of social context.

Key words: novel, literary work, artistic image, literary character, linguacultural concept.

\author{
Мунтян Антоніна Олександрівна, \\ кандидат філологічних наук, дочент, \\ Дніпровський національний університет залізничного транспорту ім. В. Лазаряна \\ Шпак Ірина Володимирівна, \\ кандидат філологічних наук, дочент, \\ Дніпровський національний університет залізничного транспорту ім. В. Лазаряна

\section{ВЕРБАЛІЗАЦІЯ ЖІНОЧИХ ХУДОЖНІХ ОБРАЗІВ В РОМАНІ ХАЛЕДА ХОССЕЙНІ «ТИСЯЧА СЯЮЧИХ СОНЦЬ»}

\begin{abstract}
Метою даного дослідження є спроба дослідити жіночі художні образи та їхню вербалізацію в романі Халеда Хоссейні «Тисяча сяючих сонць». В даному дослідженні автори роблять спробу проаналізувати маніфістації фемінінного дискурсу двох головних жіночих персонажів роману «Тисяча сяючих сониь» у сочіокультурному та лінгвостилістичному аспектах. Останніми роками вивчення жіночих дискурсів набирає значущості в різних сферах науки, а також зростає більшість досліджень і иій галузі. Розглянувши відповідні наукові праці видатних вчених, автори даної статті доходять висновку, щзо художні образи відіграють надзвичайно важливу роль у реалізачї актуальних тем і ідей будь-якого літературного твору: художні образи мають здатність продукувати нові ідеї та передавати чі ідеї читацькій аудиторії, щуоб читачі, у свою чергу, могли інтерпретувати їх відповідно культурному бекграунду, щчо забезпечую формування лінгвокультурного концепту. Дискурс жіночих персонажсв в романі Халеда Хоссейні «Тисяча сяючих сониь» варто розглядати на кількох рівнях: з одного боку, ие актуалізація особистої боротьби за базові права в родині (культурологічний аспект), а з іншого боку - це боротьба за громадянські права та свободи з точки зору сочіального контексту.
\end{abstract}

Ключові слова: роман, літературний твір, художній образ, літературний персонаж, лінгвокультурний концепт.

Introduction: Existential problems of the $20^{\text {th }}$ century have exacerbated and drastically marked sociocultural context of the $21^{\text {st }}$ century. The meaning, essence, purpose and significance of human life become pivotal point for research in a number of humanities, such as in philosophy, psychology, cognitive science, linguistics and literary science. In the sphere of sociocultural, linguacognitive and literary aspects, namely in the works of art, the verbalization of artistic images becomes of utmost importance. Artistic images embody not only physical, mental and cultural peculiarities of different nationalities and ethnic groups but also accentuate certain values, beliefs, customs and traditions formed during historical development.

The story of women fighting for their right to be a meaningful part of the human society from the historical point of view is rather vague. It has been relatively lately that these issues have become the subject of a wider discussion and scientific research. Feminism is an extremely wide and multilayered concept, studied by a number of distinguished scientists such as Dorothea Leighton and Alba Zaluar in the sphere of anthropology, Sarah Richardson [7, p. 177], Sharon Crasnow [3, p. 413] and others, however, when it comes to Khaled Hosseini, he focuses on rather simple and at the same time the most complicated aspect of this notion - a social one. He stresses out peculiarities of functioning of feministic notions in Afghan environment, its development through generations of Afghan women - through mother to daughter, and reveals both positive and negative features of the process. The scientific relevance of this study can be traced through consideration of the cultural concept of an afghan woman as an integral part of modern oriental society form the point of view of historical retrospect. 
Aim of the current piece lies in analyzing linguacultural inventory of a novel by Afghan-American writer Khaled Hosseini "A Thousand Splendid Suns" used for verbalization of female artistic images in a gender aspect.

Problems: There are several aspects of female character's discourse in Khaled Hosseini's novel "A Thousand Splendid Suns". On the one hand it deals with female discourse within a family in Afghan society and the position of a woman - her aspirations, chances for development and freedom; on the other hand the author draws attention to social context of female discourse - struggle for basic human and social rights for women under Taliban rule.

Methodology: In the current piece it is our intention to use descriptive poetic method of the analysis of the text in question as well as the literary text analysis with the implementation of feminism critique. The artistic images form a system, which exists under certain conditions of interaction and thus provides uniqueness and unity of a literary text. The system of such kind plays a key role of introduction of the most relevant thoughts of a literary piece [1]. The problem of the artistic image investigation attracted the attention of such scholars as Bart, Bakhtyn, Potebnya, Franko and others, whereas the problem of feminism was studied by such notable scientists in different spheres of knowledge as Freud, Reich, and Mead, philosophers of the Frankfurt school such as Marcuse, Adrono and others.

Research and Discussion: From time immemorial, the roles of men and women in society were strictly differentiated. At the same time, if a whole horizon of opportunities to realize oneself in this world was opened before a man, then the vocation of a woman was only to create and preserve a family hearth; to give birth and raise children; to support male partners and provide conditions for their societal development. Modern life is gradually making adjustments to these established views. The woman now faces other, no less important tasks that go far beyond the hearth. This is true for women all around the world, who started on a journey of search for female identity; it is true for women in Europe and Asia; it is true for a Christian woman as well as it is true for a Muslim.

After the matriarchy the role of women in society has been greatly diminished. Even the greatest thinkers and philosophers from Aristotle to Nietzsche to Hegel and Sartre thought of women as of lesser beings. In Simone de Beauvoir's opinion women perceived themselves as free beings however compelled to live according to the roles imposed on them by the males [2, p. 301]. The history of women fighting for their rights to be a meaningful part of society is not known to the wide majority of people. It has only in recent years that feminism became a subject of public discussions, scientific research and a subject in universities. Thanks to a number of scientific works devoted to this social phenomenon, which were published in the 80ies - 90ies of the XX century, today we can start to fathom the concept of feminism. The definition of the term even today differs from a scientist to scientist. According to Chaman Nahal, feminism is a way of being for a female, exempt from constant feeling of dependence. Under feminism rule women are independent from male members of society, religious groups and stereotypes produced by them [6, p.17-18]. The term feminism is extremely broad and not homogeneous; there is a number of waves of feminism as well as a great number of definitions and tasks, however it would be fair to note that the primary goal of feminism is to enforce the changes of the way to justice and social equality. Trying to schematize feminism Susan James points out that this movement is based on the understanding that females are at weaker position, being compared to their male counterparts. She also believes that female oppression is interpreted differently, thus it would be not correct to consider feminism as a "single philosophical doctrine" or as a unified program if one recons a political aspect [5, p. 576]. "A Thousand Splendid Suns" is a literary piece based on real events. The novel tells the story of two women, Mariam and Layla, and draws attention to instances of terrible things that happened to them in a society where their male counterparts had absolute authority supported by religious bigotry. The author also details their social status and the violence that pervades the Afghan society in which these women live.

The author tried to convey to the reader the peculiar characteristics of the time when women were oppressed in every sphere of their life. This is a very relevant story about a war without romantic decorations: not about the heroes of the war we are used to imagining, but about heroic female souls. It is a great secret (female soul) for everyone, regardless of gender. The suffering of modern society, a single nation, mothers plunge and create a lingering sad note that rings in the middle of the story. The plot captures the oriental motifs of a prayer-plunging and war-torn Afghanistan. This work introduces us to the style of the writer: Hosseini's novels are full of Afghan descriptions, as far as the events of his literary works take place in Afghanistan. The novel under analysis is not an exception and is colorful with Afghan phrases that are only sometimes directly defined:

"Nor was she old enough to appreciate the injustice, to see that it is the creators of the harami who are culpable, not the harami, whose only sin is being born" [4].

The reader is introduced to the word "harami" - the meaning of which is "bastard". This emphasizes that, from the beginning, Miriam was not a desired child, moreover, she was a girl, and the girl symbolized a certain weakness. The use of this term establishes the environment.

"There is only one, only one skill a woman like you and me needs in life, and they don't teach it in school... Only one skill. And it's this: tahamul. Endure... It's our lot in life, Mariam" [4].

Thus, we see that the stereotype of a woman's worthlessness is raised from early childhood, often by the mothers of those young girls. It goes from mother to daughter: self-loathing, insignificance, submission worthlessness. In this instance, Hosseini tried to introduce the readership to the emotional implication of the nuances of the fate of those women who belong to the lower classes.

From the beginning, the author throws us into the world of Mariam, a young girl living alone with her unmarried mother in the suburbs of Herat, showing how sad Mariam's life is. Her mother is suffering from epilepsy and the girl lives day to day with the thought of meeting her father, who runs the Herat Cinema Station, and only dreams of becoming a family member at her father's home.

"What's the sense in schooling a girl like you? It's like shining a spittoon. There is only one skill a woman like you and me needs in life [...]: tahamul. Endure" [4].

At that time, girls were forbidden to get an education, because having acquired knowledge a child would find a way to freedom.

These words are spoken by Nana when she learns that Mariam wants to go to school. In Mariam's childhood, it was not uncommon for women to be educated as far as Jalil's other daughters were expected to enter the university. Nana, however, does not value education. Eventually, education for women stops being an option for all women regardless of their social class and status under the Taliban rule. 
Nevertheless, her soulless father thought very differently even before the Taliban came to power in Afghanistan and never reckoned that Mariam might even think about having education. After her mother commits suicide, the young girl - the illegitimate daughter of a rich man who is ashamed of her existence - is quickly married to a much older shoemaker named Rashid. Soon, Mariam and Rashid's relationship deteriorates after a miscarriage. Since at that time the main function of women was childbirth, it became a tragedy for Rashid and Miriam. Ultimately, Rashid becomes more and more depressed by his wife's inability to bear a child, namely a son to show everyone Rashid's manhood and this could be confirmed only by producing an heir. For Rashid, their marriage became more tiring, he himself became incendiary and irritable, since the purpose of the woman was to raise children and maintain a household and Mariam was not successful in this capacity.

“... to see a man who's lost control of his wife" [4].

Rashid forces Mariam to wear a veil and treats her with badly disdained contempt, exposing her to mockery and insults:

“... walking past her like she was nothing but a house cat" [4].

Miriam lives in constant fear.

"His shifting moods, his volatile temperament, his insistence on steering even mundane exchanges down a confrontational path that, on occasion, he would resolve with punches, slaps, kicks, and sometimes try to make amends for with polluted apologies and sometimes not".

We understand that a woman has no right to object, she has no right to vote. The author shows us that despite the enormous amount of problems and mishaps in her life, Mariam does not become angry, cruel, or tired of hoping. Hosseini vividly describes to the reader what life is like for women in a society in which they are valued only because they can give birth to children.

The second central character of this literary piece is Laila, who is the daughter of Mariam's neighbor, and who was raised up in a liberal family with her father always present and taking care of her. He was a man with faith and love in his heart, and he believed in his daughter's fate and prestigious education

"I know you're still young, but I want you to understand and learn this now....Marriage can wait, education cannot" [4].

This advice from Laila's father shows his contemporary views on women's rights. First of all, it was true regarding education. We all understand that education is the first step towards self-realization in society. Earlier, the education of Muslim girls was envisioned as only obtaining the most basic knowledge of reading, writing and numeracy, today the doors of the most prestigious universities in the world are open to Muslim women. The life of another character in the novel, Laila, who becomes Rashid's second wife, takes an even sharper path to collapse. Although she is the coveted daughter of an intellectual who encourages the pursuit of education, Laila considers her life literally destroyed when a rocket faell on to her house.

As we see in the novel, women like Laila are the rare exceptions and they have tendency to leave present day Talib and post-Talib Afghanistan. Laila was a complete opposite of Mariam who had to share the life of a typical female stripped of basic rights solely due to unlucky circumstances. Laila never talked to Mariam because she was uneducated:

"...passed Rasheed, the shoemaker, with his burka-clad wife, Mariam, in tow” [4].

While going through this story the reader cannot help noticing that while demonstrating the duty of serving, defending and liberating their country Afghan men do not seem to notice the slavery which is a natural way of existence for their wives. This novel shows us how Laila's acquaintance with Mariam gradually and eventually turns into a great friendship, despite their husband's abusive, terrifying attitude:

"For the first time, it was not an adversary's face Laila saw but a face of grievances unspoken, burdens gone unprotested, a destiny submitted to and endured. If she stayed, would this be her own face, Laila wondered?" [4]

It is obvious that the main female characters of the novel, like the majority of Afghan women< are often victims. Mariam understands this, and this understanding helps her to reconcile with her own mother. More interestingly, it shows how Mariam becomes a kind of mother for Laila, how she guides and protects her. One of the strikingly emotional moments is the murder of Mariam's husband. As is often the case with victims of domestic violence, Mariam believes that she is somehow the reason and is the person to blame for male aggression and abuse. It takes her real long to come to peace with herself and get enough courage to stand up against him:

"Had she ever been a deceitful wife? she asked herself. A complacent wife? A dishonorable woman? Discreditable? Vulgar? What harmful thing had she willfully done to this man to warrant his malice, his continual assaults, the relish with which he tormented her?" [4]

Without any doubt, women are the most discriminated class in Islamic society because of cultural and religious beliefs, which can often be reflected in the laws of Islamic countries, affecting criminal justice, the economy, education and health systems etc. However, Khaled Hosseini points out that originally the girls of Islam had the right for education and thus they had the opportunity for independent living. Not all of the, of course, but with the rise of Taliban even those who were entitled to some basic liberties lost them. Khaled Hosseini dwells on the topic of education for Mariam; he shows the readership how difficult it is to obtain education, status and reputation for Muslims, especially Muslim girls with low social status in society.

"What's the sense schooling a girl like you? It's like shining a spittoon. And you'll learn nothing of value in those schools. There is only one, only one skill a woman like you and me needs in life, and they don't teach it in school" [4].

But at the same time, we find contradictions to these words when we get to the middle of the novel. When it comes to young girl Leila, she is the one who becomes completely independent and she begins to fight for her place in life and for her social status in society: she wants to be meaningful.

There is much debate about the role of women in the Islamic world and a lot of assumptions are being made. Unfortunately, these discussions are often negative. The most common notion of women is that they live under brutal dictatorship on the part of their husbands and fathers; they are forced on getting married, etc. In terms of her position and role in society, the woman is constantly ridiculed. For centuries, men and women have different roles to play in society. A man has a wider perspective on the realization of himself in the modern world. Women's call is to create and keep a family hearth, their task is to give birth and raise children.

"God has made us differently, you women and us men. Our brains are. You are not able to think like we can. Western doctors and their science have proven this. This is why we require only one male witness but two female ones" [4]. 
And those who do not agree to live by these rules can and should be punished. Mariam and Laila are the main characters who teach the reader the reality of life by showing how a woman exists in a backward Muslim country. They have overcome several wars throughout their lives and turn into strong and loyal women, despite being married to a mediocre and mean men and having to live under the Taliban rule.

"You know what he told his wives by way of defense? That I forced myself on him. That it was my fault. Didi? You see? This is what it means to be a woman in this world" [4].

Mariam sacrifices herself to save Leila, Tariq and the children. The main theme of Khaled Hosseini's novel "A Thousand Shining Suns" is a theme that shows discrimination against women in Afghan society. Each group that rules in Afghanistan allows men to have full control over their wives and daughters, their sisters and other female relatives: beatings, murders, loss of control over their children and humiliation are just the trifles that can be found in some Muslim countries.

"Each snowflake was a sigh heard by an aggrieved woman somewhere in the world. All the sighs drifted up the sky, gathered into clouds, then broke into tiny pieces that fell silently on the people below. As a reminder of how women suffer" [4].

Feminism is a complex and multilayered notion, which can be treated differently: from manifestations of justified fight for women's rights to an extreme warlike trend, which is completely destructive primarily for women. Some vehement feminists are constantly pushing women to compete with men in everything, and often even in the field of hard physical labor, which is a bit exaggeration as far as it is biological fact that men and women are not the same. When leaving the realm of social and legal spheres, the fight for gender equality may to some extent leave the realm of adequacy. In Hosseini's opinion the gender equality is not about equal amount of physical work, but about just opportunities and fare admittance of value brought by every individual, regardless of his or her gender affiliation: upbringing of children is as important as defending the country.

Conclusion: Correction of society, according to Khaled Hosseini, should begin with each individual fighting for the awakening of basic positive human emotions. That is why the main female characters of the novel are in constant battle with natural circumstances that interfere with the truly free life, thought, and love. The writer hopes that in the future there will come a temporary victory over the world of social absurdity. In his novel "A Thousand Splendid Suns" Khaled Hosseini creates a narrative, where the center is a small world of family life with motifs of struggle, suffering, fight and reconciliation. Naturally his novel if full of a number of striking images, however the two protagonists of the story are Mariam and Laila. They are both extremely different and at the same time extremely alike: different in terms of original opportunities and similar in terms of life circumstances brought by the cannons of male/ Muslin/Talib society. These women oppose not only absurd family cannons, but also senseless societal norms, both of relatively tolerable Afghan customs and outrages dogmas of Taliban. They struggle for the right of choice of their own destiny and possibility to experience their own luck. Khaled Hosseini truthfully reveals the inner world of female characters in his novels: analyzes their actions, and justifies the causes of their tragic fate. He tries to depict the functioning of feminist trends in modern Afghan society.

\section{Література:}

1. Русова Н. Ю. Терминологический словарь-тезаурус по литературоведению. От аллегории до ямба. М.: Флинта, Наука, 2004.

2. Beauvoir S., The Second Sex. rpt. Harmondsworth: Penguin, 1952. P. 301.

3. Crasnow Sh. Feminist Philosophy of Science: Values and Objectivity. Philosophy Compass. 2013. 8 (4). P. 413.

4. Hosseini Kh. "A Thousand Splendid Suns". Riverhead Books. 2007. P. 144. URL https://medium.com/@kneukel/pdf-a-thousandsplendid-suns-full-pages-f12bb67c8231.

5. James S. Feminism. In Edward Craig (ed.), Routlege., Routledge Encyclopedia of Philosophy, London: Routledge, 1998; $10:$ P. 576.

6. Nahal Ch., Feminism in English Fiction: Forms and Variations, Feminism and Recent Fiction in English New Dehli: Prestige Books, 1991. P. 17-18.

7. Richardson S. "Feminist philosophy of science: history, contributions, and challenges”. Synthese. 2010. P. 177 (3). 